\title{
PENINGKATAN PENDUDUK YANG MENJADI PROBLEMA SOSIAL
}

\author{
Muhammad Rifani \\ 1810128110019 \\ Program Studi Pendidikan IPS, FKIP Universitas Lambung Mangkurat \\ rifani089@gmail.com
}

Peningkatan populasi manusia kian meningkat pertahun Badan Pusat Statistik (BPS) mencatat Indeks Pembangunan Manusia (IPM) Indonesia tahun 2019 sebesar 71,92, lebih tinggi dari IPM tahun 2018 yang sebesar 71,39. Kenaikan IPM ini sejalan dengan perbaikan angka harapan hidup, kualitas pendidikan, dan serta daya beli masyarakat. Negara - negara yang padat penduduk nya juga diantaranya negara tiongkok dan india negara tersebut sangat padat penduduknya. Peningkatan penduduk menjadi masalah bagi negaranya dan masyarakat, melunjaknya penduduk akan mengakibatkan menurunya kualitas masyarakat, menurunnya sumber bahan pangan, meningkatnya angka pengangguran, dan persaingan yang semakin ketat untuk bertahan hidup. Masalah - masalah ini ditimbulkan oleh masyarakatnya pindah ke daerah padat untuk memenuhi kebutuhannya daerah padat seperti di kota - kota yang di sebut Urbanisasi, dampak yang di timbulkan dampak negatif bagi negara angka yang semakin meningkat apabila tidak di iringi dengan pembangunan pemerataan setiap daerah akan menibulkan permasalahan sosial.

Permasalahan sosial diantarnya juga peningkatan penduduk ini peningkatan sumber daya manusia yang meningkat tetapi kualitas manusianya rendah mengakibatkan penurunannya kualitas penduduk sehingga banyak nya timbul masalah ekonomi, kriminalitas, dan kesehatan. Masalah ekonomi merupakan masalah pada kebutuhan keluarga atauoun individu yang tidak terpenuhi, dari segi pekerjaan dan kebutuhan pangan yang terbatas. Sulitnya mencari pekerjaan mengakibatkan banyaknya pengangguran terpelajar karena 
persaingan sangat ketat dan lowongan pekerjaan tidak banyak masalah tersebut merupakan masalah sosial yang harus di pecahkan sehingga dapat meningkatkan pertumbuhan negara, adapun dari sudut pandang masalah kriminalitas di karena rendahnya pendidikan sehingga sulit mendapatkan pekerjaan dan juga kriminalitas ini menjadi meresahkan masyarakat, dari sudut pandang kesehatan kurangnya ketersedian air bersih dan kebutuhan makanan sehat di karenakan mengalami penurunan terhadap ketersedia bahan kebutuhan pangan, padatnya penduduk mengalami pengurangan kualitas udara bersih berkurang di karenakan banyaknya polusi udara. Permasalahan sosial tersebut merupakan dampak dari peningkatan penduduk yang menjadi problem sosial di negara.

Permasalahan ini dapat diatasi dalam berbagai sudut pandang sehingga menemukan titik masalah dalam pendekatan Transdisiplin masalah peningkatan penduduk ini adanya dorongan terhadap masyarakat dalam melakukan urbanisasi karena kebutuhan kurang terpenuhi dan keterpaksaan kerja di kota, masalah ini merupakan suatu permasalahan yang di alami di wilayah perkotaan. Maraknya penduduk yang melonjak mengakibatkan persedian pangan mengurang dan persaingan sangat ketat dalam hal mencari pekerjaan, pemerintahan dapat turut mengatasi masalah tersebut agar mengurangi angka kemiskinan negara dengan menerapkan transmigrasi. 